\title{
G-CSF prevents cerebral infarction and maintain muscle strength in experimental model of ischemic stroke
}

\author{
Rafaela Aires ${ }^{1}$, Brenna Lepaus Monteiro², Rayssa Florentina Scárdua², Brunelli da Rós Peruch², \\ Lohayne Simões Barbosa ${ }^{2}$, Manoel Ramos Penha ${ }^{2}$, Marco Cunegundes Guimarães ${ }^{3}$, Breno Valentim Nogueira ${ }^{3 *}$
}

From 5th Congress of the Brazilian Biotechnology Society (SBBIOTEC)

Florianópolis, Brazil. 10-14 November 2013

\section{Background}

Cerebral infarction is an ischemic stroke resulting from a disturbance in the blood vessels supplying blood to the brain, being the leading cause of physical and cognitive disabilities in adults [1]. The currently approved administration of thrombolytic agents is effective only within about the first 3 hours poststroke [2]. Recent studies have demonstrated that administration of growth factors can reduce stroke size or functional deficits [3]. Among the factors, the granulocyte colony-stimulating factor (G-CSF) demonstrated ability to promote differentiation of hematopoietic cells, as well as neurogenesis and promoting formation of new synapses $[4,5]$. Therefore, the aim of this study was to evaluate if the protective role of G-CSF in cerebral ischemia is associated with the maintenance of muscle strength.

\section{Methods \\ Swiss webster mice (Mus musculus) males $(\mathrm{n}=16)$, weighing approximately $30 \mathrm{~g}$, underwent global cerebral ischemia. Was occluded common carotid arteries for 80 minutes, and after this period the blood flow of the common carotid artery was released, while the arterial blood supply to the left remained interrupted. The stroke animals received vehicle (5\% glucose solution) or were treated with G-CSF at a dose of $100 \mathrm{mg} / \mathrm{kg} /$ day, administering it after 24 hours of treatment. All the experimental procedures were performed in accordance withNational Institutes of Health (NIH) guidelines, and study protocols were previously approved by the Institu- tional Animal Care and Use Committee (CEUA Protocol \\ ${ }^{3}$ Postgraduate Program in Biotechnology Federal University of Espirito Santo - PPGBIOTEC/UFES, Vitoria, Brasil \\ Full list of author information is available at the end of the article}

\# 011/2011). The measurement of the strength of the mice was performed in the pre and post surgery through software coupled to a force transducer. The quantification of the area of cerebral infarction using 2,3,5-triphenil tetrazolium chloride was established by morphometric analysis using Image J program (NIH). The data are presented as means \pm SEM. Statistical analysis was performed using Student's $t$ test for comparison of groups using the software Prism ${ }^{\circledR} 5.0$ (GraphPad, San Diego, CA, USA). p values $<0.05$ were considered to be statistically significant.

\section{Results and conclusions}

A significant increase in the number of circulating leukocytes in the animals treated with G-CSF ( $=$ AVE + vehicle $2,550 \pm 283 / \mathrm{mm} 3$ vs. G-CSF $+\mathrm{AVE}=15,650 \pm 1,294 /$ $\mathrm{mm} 3, \mathrm{p}<0.01)$ was observed. The strength after surgery was significantly higher $(\mathrm{p}<0.05)$, in the group treated with G-CSF $(88 \pm 4 \mathrm{~g} ; t$ value $=0.0473)$ when compared with vehicle group $(71 \pm 5 \mathrm{~g})$. The areal extent of cerebral infarction was significantly lower $(\mathrm{p}<0.05)$ in animals treated with G-CSF $\left(0.205 \pm 0.03 \mathrm{~cm}^{2}\right.$; Student $t$ value $=$ $0.0331)$ compared to the control group $\left(0.401 \pm 0.07 \mathrm{~cm}^{2}\right)$.

Our results demonstrate the neuroprotective effect of G-CSF in mice undergoing ischemic brain, thereby contributing to the reduction of neurofunctional impairment caused by stroke, as the maintenance of strength in the treated group.

\section{Acknowledgements}

FAPES N ${ }^{0}$ 012/2011 Universal, Grant Process: 54681022; CNPq/FAPES-PRONEX $N^{0}$ 013/2011, Grant Process: 55203345. 


\section{Authors' details}

${ }^{1}$ EMESCAM/UFES, Vitoria, Brasil. ${ }^{2}$ Federal University of Espirito Santo, UFES,

Vitoria, Brasil. ${ }^{3}$ Postgraduate Program in Biotechnology Federal University of Espirito Santo - PPGBIOTEC/UFES, Vitoria, Brasil.

Published: 1 October 2014

\section{References}

1. Zhao LR, Piao CS, Murikinati SR, Gonzalez-Toledo ME: The Role of Stem Cell Factor and Granulocyte-Colony Stimulating Factor in Treatment of Stroke. Recent Pat CNS Drug Discov 2013, 8(1):2-12.

2. Greenberg DA, Jin K: Growth Factors and Stroke. NeuroRx 2006, 3(4):458-465.

3. Kidd PM: Integrated brain restoration after ischemic stroke-medical management, risk factors, nutrients, and other interventions for managing inflammation and enhancing brain plasticity. Altern Med Rev 2009, 14(1):14-35.

4. Toth ZE, Leker RR, Shahar T, Pastorino S, Szalayova I, Asemenew B, Key S, Parmelee A, Mayer B, Nemeth K, Bratincsák A, Mezey E: The combination of granulocyte colony stimulatory factor and stem cell factor significantly increases the number of bone marrow derived endothelial cells in brains of mice following cerebral ischemia. Blood 2008, 111(12):5544-5552.

5. Hokari M, Kuroda S, Chiba Y, Maruichi K, Iwasaki Y: Synergistic effects of granulocyte-colony stimulating factor on bone marrow stromal cell transplantation for mice cerebral infarct. Cytokine 2009, 46(2):260-266.

doi:10.1186/1753-6561-8-S4-P42

Cite this article as: Aires et al:: G-CSF prevents cerebral infarction and maintain muscle strength in experimental model of ischemic stroke. BMC Proceedings 2014 8(Suppl 4):P42.

\section{Submit your next manuscript to BioMed Central} and take full advantage of:

- Convenient online submission

- Thorough peer review

- No space constraints or color figure charges

- Immediate publication on acceptance

- Inclusion in PubMed, CAS, Scopus and Google Scholar

- Research which is freely available for redistribution

Submit your manuscript at www.biomedcentral.com/submit
Biomed Central 